\title{
Studi Evaluatif Pelaksanaan Program Pendidikan TAMAN Kanak-Kanak (TK)
}

\author{
I Gede Nuarta ${ }^{1}$, I Made Yudana ${ }^{2}$, Nyoman Natajaya ${ }^{3}$ \\ ${ }^{123} J u r u s a n$ administrasi pendidikan Program pasca sarjana \\ Universitas pendidikan ganesha \\ Singaraja, Indonesia \\ e-mail: nuartagde175@gmail.com ${ }^{1}$, made.yudana@undiksha.ac.id², \\ nyoman.natajaya@undiksha.ac.id ${ }^{3}$
}

\begin{abstract}
Abstrak
Tujuan dari penelitian ini adalah untuk mempelajari pelaksanaan program Pendidikan di Taman Kanak-Kanak (TK) yang ditinjau dari konteks, input, proses, dan produk. Penelitian ini adalah penelitian ekspost facto dengan menggunakan metode evaluasi CIPP. Pengambilan data dengan kuesioner yang diisi oleh 105 responden guru Taman Kanak-Kanak (TK) di Kecamatan Seririt. Analisis data menggunakan uji T. Hasil analisis menunjukkan dintinjau dari: (1 contex menunjukkan hasil positif $(+)$; (2) input menunjukkan hasil negatif $(-)$; (3) proses menunjukkan hasil positif $(+)$; (4) produk menunjukkan hasil positif $(+)$; (5) konteks, input, proses, dan produk pada Kuadran Glickman menunjukkan implementasi program pendidikan termasuk ke dalam kategori efektif; dan (6) Kendala-perpindahan yang terlibat dalam pelaksanaan program Pendidikan antara lain: (a (b) Masih terbatas fasilitas kesenian yang memadai untuk melaksanakan kegiatan kesenian; (c) Standar sanitasi lingkungan masih rendah, misalnya tempat sampah yang digunakan tanpa tutup, sehingga aroma sampah dibuang sesuai kebutuhan ; (d) Pelatihan kurang terkait buku panduan pelaksanaan pendidikan dan persiapan dokumen hasil pengawasan pelaksanaan kegiatan TK; (e) Pelatihan guru terkait kurang terkait RPPM dan RPPH; (f) Masih rendahnya jumlah dan Keragaman jenis bahan ajar serta alat permainan edukatif; (g) Kurangnya keterampilan guru menerapkan pembelajaran saintifik dan kontekstual untuk pembelajaran TK.
\end{abstract}

Kata Kunci: evaluasi cipp, program pendidikan, tk

\section{Abstract}

The purpose of this research is to study the implementation of Education programs in kindergartens in terms of context, input, process, and product. This research is an ex post facto study using the CIPP evaluation method. Retrieval of data with a questionnaire filled out by 105 respondents in kindergarten teachers in Seririt District. Data analysis using $T$ test. The results of the analysis showed a review of: (1 context showed positive results (+); (2) inputs showed negative results (-); (3) processes showed positive results (+); (4) products showed results positive (+); (5) context, input, process, and product in the Glickman Quadrant show that the implementation of education programs is included in the effective category, and (6) The constraints involved in implementing the Education program include: $(a(b)$ There are still limited adequate arts facilities to carry out artistic activities, (c) Environmental sanitation standards are still low, for example trash bins are used without a lid, so that the smell of garbage is disposed of as needed, (d) Training is lacking related to education implementation manuals and preparation of supervision documents. implementation of kindergarten activities; (e) teacher training is less related to RPPM and RPPH, (f) the number and variety of teaching materials and educational toys are still low; $(g)$ teacher skills in applying scientific and contextual learning to kindergarten learning

Keywords: cipp evaluation, education program, kindergarten 


\section{Pendahuluan}

Satuan atau program PAUD adalah layanan PAUD yang dilaksanakan pada suatu lembaga pendidikan dalam bentuk Taman Kanak-kanak (TK)/Raudatul Athfal (RA)/Bustanul Athfal (BA), Kelompok Bermain (KB), Taman Penitipan Anak (TPA), dan Satuan PAUD Sejenis (SPS) (Peraturan Menteri Pendidikan dan Kebudayaan Republik Indonesia Nomor 137 Tahun 2014 Tentang Standar Nasional Pendidikan Anak Usia Dini). Dalam penyelenggaraan PAUD khususnya TK sekarang ini masih ditemukan beberapa permasalahan diantaranya rendahnya kualitas guru dan terbatasnya sarana/prasarana untuk kegiatan pembelajaran. Permasalahan lainnya adalah pembelajaran yang monoton dan berfokus pada guru, minimnya alat peraga dan buku pegangan untuk bahan ajar. Permasalahan-permasalahan tersebut harus menjadi perhatian utama untuk memulai perbaikan penyelenggaraan pendidikan di TK. TK merupakan pendidikan pra sekolah yang membentuk kepribadian anak, sehingga TK merupakan pondasi penting pendidikan anak.

Salah satu upaya pemerintah dalam mengatasi masalah tersebut adalah mengeluarkan Peraturan Menteri Pendidikan Nasional nomor 58 tahun 2009 tentang standar PAUD, yang kemudian direvisi menjadi Peraturan Menteri Pendidikan Nasional Nomor 137 tahun 2014 tentang Standar PAUD yang terdiri atas (1) Standar Tingkat Pencapaian Perkembangan Anak Usia Dini selanjutnya disebut STPPA; (2) Standar Isi; (3) Standar Proses; (4) Standar Penilaian; (5) Standar Pendidik dan Tenaga Kependidikan; (6) Standar Sarana Prasana; (7) Standar Pengelolaan; dan (8) Standar Pembiayaan. Standar PAUD diharapkan menjadi standar acuan minimal bagi masyarakat dan stakeholders dalam memberikan pelayanan pendidikan yang berkualitas bagi anak usia dini. Untuk mempermudah pelaksanaan Peraturan Menteri Pendidikan Nasional tersebut dibuatlah petunjuk teknisnya (Juknis) penyelengaraan PAUD untuk jalur formal, nonformal dan informal sebagai pedoman dalam penyelengaraan PAUD. Namun dalam pelaksanaannya masih ditemukan ketidaksesuaian dengan peraturan,

Oleh sebab itu saat ini dibutuhkan evaluasi dan penilaian terhadap tenaga pendidik dan akan dievaluasi juga tenaga kependidikannya. Untuk membentuk sekolah yang bermutu, bermoral dan berkualitas baik. Evalusi tenaga pendidik berguna untuk menghasilkan tenaga pendidik yang berkualitas yang bermutu dan layak untuk di katakan sebagai tenaga pendidik, bukan hanya sekedar guru yang mengajar dan mengisi daftar hadir disekolah. Tapi sebagai pembimbing dan pendidik haruslah menunjukkan perilaku positif terhadap anak didiknya dan masyarakat luas.

Dalam prosesnya, pendidikan menjadikan tujuan sebagai sasaran ideal yang hendak dicapai dalam program dan diproses dalam produk kependidikan atau output kependidikan. Untuk mengetahui ketercapaian suatu tujuan kegiatan yaitu dengan evaluasi. Dengan evaluasi, maka suatu kegiatan dapat diketahui atau ditentukan taraf kemajuannya. Berhasil atau tidaknya pendidikan dalam mencapai tujuannya dapat dilihat setelah dilakukan evaluasi terhadap konteks, input, proses, dan produk yang dihasilkannya. Dalam usaha untuk mencapai misi dan tujuan itu perlu diketahui apakah usaha yang dilakukan sudah sesuai dengan tujuan.

Apabila program sekolahnya baik maka kegiatan-kegiatan sekolahnya pun akan baik, dan begitu pula sebaliknya apabila program sekolahnya tidak bermutu maka sudah barang tentu kegiatan-kegiatan sekolahnya tidak akan bermutu pula. Berkaitan dengan program sekolah ini sangat berkaitan dengan ketercapaian tujuan pendidikan.

Berdasarkan pada uraian di atas tampak jelas bahwa program sekolah sangat penting dalam dunia persekolahan. Oleh karena itulah, mengingat pentingnya program sekolah, maka untuk menjaga mutu dan pengembangannya ke arah yang lebih baik, program sekolah ini harus selalu dievaluasi secara berkelanjutan. Sehingga dengan dilakukannya evaluasi yang kontinyu, dari waktu ke waktu program sekolah akan semakin bermutu. Dari hasil evaluasi inilah, dapat dilakukan perbaikan-perbaikan, pengembangan, dan peningkatan program 
sekolah sehingga akan semakin sempurna sesuai dengan tuntutan dan harapan dalam rangka mencapai tujuan pendidikan.

Melakukan evaluasi program adalah kegiatan yang dimaksudkan untuk mengetahui seberapa tinggi tingkat keberhasilan dari kegiatan yang direncanakan. Oleh sebab itu, dibutuhkan evaluasi dan penilaian terhadap tenaga pendidik dan kependidikan. Untuk membentuk sekolah yang bermutu, bermoral dan berkualitas baik. Evalusi tenaga pendidik mermanfaat untuk menilai dan meningkatkan kualitas guru dalam semua ranah kompetensinya. Evaluasi perlu dilakukan secara menyeluruh untuk melihat secara holistic suatu program pendidikan TK berjalan baik atau tidak.

Penelitian Kasrani (2016) bertujuan untuk mengevaluasi pemenuhan standar penyelenggaraan Pendidikan Anak Usia Dini di Kecamatan Tanjung Harapan Kabupaten Paser Kalimantan Timur. Penelitian ini menggunakan pendekatan kualitatif dengan teknik pengumpulan data melalui (1) wawancara mendalam, (2) observasi, dan (3) dokumentasi. Analisis data dilakukan dengan menggunakan metode CIPP yaitu terdiri dari komponen konteks (Context), masukan (Input), proses (Process), dan hasil (Product). Hasil penelitian, yaitu: (1) tingkat pendidikan kepala sekolah dan guru belum sesuai dengan kriteria dalam standar PAUD, masih dijumpai sebanyak 78\% berlatar pendidikan SMA; (2) sebanyak $80 \%$ guru belum pernah mendapatkan pelatihan tentang pendidikan anak usia dini; (3) fasilitas gedung tempat pelaksanaan proses pembelajaran masih sangat minim; (4) fasilitas alat belajar di kelas yang berupa alat peraga edukatif (APE) sangat minim dalam jenis maupun jumlahnya; (5) fasilitas tempat pembelajaran di luar kelas sangat tidak memadai; dan (6) belum ada kegiatan pembinaan bagi para kepala sekolah dan guru. Dari hasil evaluasi ini telah dibuat rekomendasi untuk pemerintah beserta pihak-pihak yang berwenang bahwa untuk dapat mencapai kualitas hasil belajar yang tinggi pada anak usia dini, harus ada pendidikan dan pelatihan bagi pendidik dan tenaga kependidikan. Penelitian ini dilaksanakan di tempat dengan situasi dan kondisi yang berbeda dengan Kecamatan Seririt, sehingga pasti banyak terdapat perbedaan karakter data yang akan diperoleh, karena setiap daerah memiliki kelebihan dan kekurangan, begitu juga daya dukung implementasi PAUD yang berbeda.

Hasil penelitian Anamara (2014) menyatakan bahwa pelaksanaan standar PAUD belum berjalan efektif, dimana kualifikasi akademik guru adalah tamatan SPGTK, kualifikasi akademik kepala sekolah setingkat DII PGTK, sekolah tidak memiliki kurikulum, program kegiatan semester dan rencana kegiatan mingguan/RKM disusun melalui wadah IGTKI, dan penilaian terhadap anak didik belum dilakukan secara individu. Tentang sarana dan prasarana, gedung sekolah didirkan dekat makam, gedung belakang dan samping kanan sekolah berbatasan dengan lahan yang lebih tinggi menyerupai tebing, alat permainan edukatif/APE dalam ruang kelas dalam kondisi tidak bersih, tidak diperbarui dan masih ada yang belum sesuai dengan area yang ada. Alat permainan luar ruang beralaskan lantai belum memperhatikan faktor keselamatan anak. Fokus penelitian Anamara (2014) pada keterlaksanaan standar PAUD, sedangkan penelitian ini focus melakukan evaluasi dengan CIPP terhadap pelaksanaan PAUD di Kecamatan Seririt.

Beberapa permasalahan yang terjadi di TK di Kecamatan Seririt dalam membuat perencanaan dan kegiatan pembelajaran, guru belum memperhatikan kebutuhan, minat dan karakteristik anak. Penilaian perkembangan anak didik dicatat seadanya tanpa menggunakan format yang baik untuk masing-masing anak didik. Hal lainnya adalah guru melakukan penilaian secara general maksudnya capaian perkembangan anak tidak dicatat secara individu melalui salah satu instrumen penilaian melainkan dicatat secara bersamasama atau digabung antara anak yang satu dengan yang lainnya. Terkait metode pembelajaran, maka TK di Kecamatan Seririt masih menerapkan pembelajaran yang berpusat pada guru, anak didik hanya mengikuti instruksi gurunya. Kondisi lainnya masih terbatasnya sarana belajar baik yang dipakai guru dalam proses pembelajaran maupun yang ada di sentra. Tentunya kondisi-kondisi 
yang dipaparkan di atas tidak diharapkan berlangsung dalam waktu yang panjang. Pihak sekolah dan juga pemerintah yang diwakili oleh Dinas Kabupaten setempat perlu mengatasi kondisi yang ada guna perbaikan mutu dan peningkatan kualitas sekolah dan anak didiknya. Dehan demikian peran terberat pemerintah dan lembaga-lemnbaga TK saat ini adalah melatih guru-guru TK dan memastikan guru yang menyentuh anak-anak memiliki kemampuan minimal, sehingga dimanapun dia melakukan, apapun bentuk satuan pendidikannya, guru tersebut harus menguasai prinsip-prinsip dasarnya.

Berdasarkan uraian tersebut diatas maka peneliti tertarik untuk melakukan penelitian mengenai "Studi Evaluatif Pelaksanaan Program Pendidikan Taman Kanak-Kanak (TK) di Kecamatan Seririt".

Tujuan dari penelitian ini adalah untuk mengetahui: (1) Pelaksanaan program Pendidikan Taman Kanak-Kanak (TK) di Kecamatan Seririt ditinjau dari contex; (2) Pelaksanaan program Pendidikan Taman Kanak-Kanak (TK) di Kecamatan Seririt ditinjau dari input; (3) Pelaksanaan program Pendidikan Taman Kanak-Kanak (TK) di Kecamatan Seririt ditinjau dari process; (4) Pelaksanaan program Pendidikan Taman Kanak-Kanak (TK) di Kecamatan Seririt ditinjau dari product, (5) Pelaksanaan program Pendidikan Taman Kanak-Kanak (TK) di Kecamatan Seririt ditinjau dari contex, input, process, dan product; (6) Kendala-kendala yang dihadapi dalam pelaksanaan program Pendidikan Taman Kanak-Kanak (TK) di Kecamatan Seririt.

\section{Metode}

Penelitian ini dilaksanakan dengan menggunakan rancangan penelitian evaluatif dengan hampiran kuantitatif deskriptif. Rancangan ini dipilih dengan pertimbangan untuk mengevaluasi program Program Pendidikan Anak Usia Dini (PAUD).

Model evaluasi yang digunakan adalah model CIPP. Model evaluasi CIPP adalah model evaluasi yang tujuannya untuk mengambil keputusan dalam merencanakan, melaksanakan, dan mengembangkan suatu program (Fuddin, 2007). Mbulu (1995: 62) model CIPP merupakan singkatan (akronim) dari contect evaluation, input evaluation, process evaluation, dan product evaluation.

Penelitian ini dilaksanakan di delapan (8) TK di Kecamatan Seririt dilaksanakn dari bulan Desember 2019, data diambil pada minggu kedua bulan Maret 2020. Total populasi penelitian yang terdiri dari kepala sekolah, guru, staf pegawai, dan ketua komite/Yayasan adalah 144 orang, dengan metode purposive sampling yang jumlah sampelnya dihitung dengan Nomogram Harry King yaitu $70 \%$ dari jumlah populasi menjadi 101, untuk menghindari bias data diambil sampel 105. Subjek penelitian CIPP ditunjukkan pada Tabel 01.

\section{Tabel 1}

Subjek Penelitian CIPP

\begin{tabular}{clcc}
\hline No & \multicolumn{1}{c}{ Subjek Penelitian } & Populasi & Sampel \\
\hline 1 & Kepala Sekolah & 29 & 22 \\
2 & Guru & 63 & 45 \\
3 & Pegawai & 23 & 17 \\
4 & Ketua komite/yayasan & 29 & 21 \\
\hline & Jumlah & 144 & 105 \\
\hline
\end{tabular}

Instruman utama yang digunakan dalam penelitian ini adalah lembar kuesioner yang didukung dengan data observasi dan wawancara. Kuesioner dalam penelitian ini bersifat tertutup karena telah disediakan jawaban, sehingga responden tinggal memilih salah satu dari altrnatif jawaban yang dipilinnya sesuai dengan kondisinya. Kuesioner yang digunakan telah dilakukan uji ahli, serta uji coba validitas dan reliabilitas lapangan, diperoleh dari 127 butir 
pernyataan dalam kuesioner, tidak valid satu sehingga digunakan 126 butir pernyataan. Data dianalisis dengan statistik deskriptif dan evaluasi CIPP menggunakan transformasi data ke T skor kemudian dimasukkan ke dalam kuadran Glickman untuk mengetahui efektivitas pelaksanaan program Pendidikan Taman Kanak-Kanak (TK) di Kecamatan Seririt (Agung, 2016: 17-76; Agung \& Koyan, 2016: 37).

\section{Hasil dan Pembahasan}

Hasil uji statistik deskriptif data veariabel contex (X1), input (X2), process (X3), dan product (X4) ditunjukkan pada Tabel 02.

Tabel 2

Statistik Deskriptif Veariabel Contex (X1), Input (X2), Process (X3), dan Product (X4)

\begin{tabular}{lcccc}
\hline \multicolumn{1}{c}{ Statistik } & Contex $(\mathbf{X} \mathbf{1})$ & Input $(\mathbf{X 2})$ & Process $(\mathbf{X 3})$ & Product $(\mathbf{X} \mathbf{)})$ \\
\hline $\mathrm{N}$ & 105,00 & 105,00 & 105,00 & 105,00 \\
Rerata & 16,50 & 246,51 & 152,51 & 74,90 \\
Median & 17,00 & 247,00 & 152,00 & 75,00 \\
Modus & 17,00 & 244,00 & 154,00 & 73,00 \\
Std. Deviasi & 2,19 & 9,03 & 6,57 & 4,11 \\
Varians & 4,79 & 81,56 & 43,12 & 16,91 \\
Skewness & $-0,89$ & $-0,22$ & 0,15 & 0,17 \\
Kurtosis & 0,66 & $-0,24$ & 0,38 & $-0,19$ \\
Range & 10,00 & 41,00 & 37,00 & 20,00 \\
Minimum & 10,00 & 225,00 & 133,00 & 65,00 \\
Maksimum & 20,00 & 266,00 & 170,00 & 85,00 \\
Sum & 1733,00 & 25884,00 & 16014,00 & 7865,00 \\
\hline
\end{tabular}

Tabulasi data hasil penelitian variabel contex (X1) dari 105 orang responden ditunjukkan pada Tabel 03.

Tabel 03

Distribusi Frekuensi Skor Variabel Contex (X1)

\begin{tabular}{ccccccc}
\hline No. & \multicolumn{2}{c}{ Interval Kelas } & $\begin{array}{c}\text { Nilai } \\
\text { Tengah }\end{array}$ & $\begin{array}{c}\text { Frekuensi } \\
\text { Absolut }\end{array}$ & $\begin{array}{c}\text { Frekuensi Relatif } \\
\text { (\%) }\end{array}$ \\
\hline 1 & 10 & - & 11 & 10,5 & 4 & 4 \\
2 & 12 & - & 13 & 12,5 & 6 & 6 \\
3 & 14 & - & 15 & 14,5 & 19 & 18 \\
4 & 16 & - & 17 & 16,5 & 39 & 37 \\
5 & 18 & - & 19 & 18,5 & 33 & 31 \\
6 & 20 & - & 21 & 20,5 & 4 & 4 \\
\hline \multicolumn{7}{r}{} \\
\hline
\end{tabular}

Berdasarkan Tabel 3 data variabel contex (X1) $37 \%$ pada kelas interval dengan nilai tengah 16,5 dan $31 \%$ pada kelas interval dengan nilai tengah 18,5; dari nilai maksimal 20 . Pada variabel variabel contex (X1) diperoleh: (1) TK di Kecamatan Seririt sudah memiliki surat izin pendirian TK oleh Kepala Dinas kabupaten/kota atau kepala SKPD masih berlaku; (2) TK di Kecamatan Seririt sudah memiliki dokumen hasil penilaian kelayakan; (3) TK di Kecamatan 
Seririt sudah memiliki dokumen Rencana Induk Pengembangan (RIP) TK; dan (4) TK di Kecamatan Seririt sudah memiliki dokumen rencana pencapaian standar penyelenggaraan TK.

Tabulasi data hasil penelitian variabel input (X2) dari 105 orang responden ditunjukkan pada Tabel 04.

Tabel 4.

Distribusi Frekuensi Skor Variabel Input (X2)

\begin{tabular}{|c|c|c|c|c|c|c|}
\hline No. & \multicolumn{3}{|c|}{ Interval Kelas } & \multirow{2}{*}{$\begin{array}{c}\begin{array}{c}\text { Nilai } \\
\text { Tengah }\end{array} \\
227,5\end{array}$} & \multirow{2}{*}{$\begin{array}{c}\text { Frekuensi } \\
\text { Absolut }\end{array}$} & \multirow{2}{*}{$\begin{array}{c}\text { Frekuensi } \\
\text { Relatif (\%) } \\
6\end{array}$} \\
\hline 1 & 225 & - & 230 & & & \\
\hline 2 & 231 & - & 236 & 233,5 & 7 & 7 \\
\hline 3 & 237 & - & 242 & 239,5 & 21 & 20 \\
\hline 4 & 243 & - & 248 & 245,5 & 23 & 22 \\
\hline 5 & 249 & - & 254 & 251.5 & 28 & 27 \\
\hline 6 & 255 & - & 260 & 257.5 & 14 & 13 \\
\hline 7 & 261 & - & 266 & 263,5 & 6 & 6 \\
\hline & Jumlah & & & & 105 & 100 \\
\hline
\end{tabular}

Tabel 4 menunjukkan data variabel input (X2) 27\% masuk memiliki nilai tengah 251,5, dan $22 \%$ memiliki nilai tengah 245 . Kelemahan yang ditunjukkan pada variabel input pelaksanaan program pendidikan TK di Kecamatan Seririt berdasarkan data penelitian antara lain: (1) Beberapa TK belum memiliki fasilitas ruang kelas yang ada memadai untuk kegiatan pembelajaran; dan (2) Beberapa TK belum memiliki sarana kesenian yang memadai untuk melaksanakan kegiatan kesenian; (3) Sebagian besar TK belum memiliki ruang UKS (Usaha Kesehatan Sekolah) dengan kelengkapan administrasi dan P3K (Pertolongan Pertama Pada Kecelakaan) dan segala aktivitasnya; (4) Belum ada tempat sampah yang tertutup dan tidak tercemar, dapat dikelola setiap hari; (5) Belum ada buku panduan pelaksanaan pendidikan; dan (6) TK di Kecamatan seririt belum memiliki dokumen laporan hasil pengawasan pelaksanaan kegiatan TK. Kesenjangan variabel input sangat jelas terlihat antara TK negeri dan TK swasta, karena sumber pembiayaan yang berbeda sehingga alokasi dana untuk pengembangan sarana dan prasaranapun berbeda.

Tabulasi data hasil penelitian variabel process (X3) dari 105 orang responden ditunjukkan pada Tabel 04.

Tabel 04

Distribusi Frekuensi Skor Variabel Process (X3)

\begin{tabular}{|c|c|c|c|c|c|c|}
\hline \multirow{2}{*}{$\begin{array}{c}\text { No. } \\
1\end{array}$} & \multicolumn{3}{|c|}{ Interval Kelas } & Nilai & Frekuensi & Frekuensi \\
\hline & 133 & - & 137 & 135 & 1 & 1 \\
\hline 2 & 138 & - & 142 & 140 & 4 & 4 \\
\hline 3 & 143 & - & 147 & 145 & 17 & 16 \\
\hline 4 & 148 & - & 152 & 150 & 31 & 30 \\
\hline 5 & 153 & - & 157 & 155 & 31 & 30 \\
\hline 6 & 158 & - & 162 & 160 & 13 & 12 \\
\hline 7 & 163 & - & 167 & 165 & 6 & 6 \\
\hline 8 & 168 & - & 172 & 170 & 2 & 2 \\
\hline Jumlah & & & & & 105 & 100 \\
\hline
\end{tabular}


Berdasarkan Tabel 4 diperoleh data 30\% data masuk nilai tengah 150 dan 155. Beberapa kelemahan yang diperoleh berdasarkan hasil observasi, wawancara, dan penyebaran kuesioner: (1) Guru belum memiliki Rencana Pelaksanaan Pembelajaran Mingguan (RPPM); (2) Guru memiliki Rencana Pelaksanaan Pembelajaran Harian (RPPH), namun kebanyakan hasil coppy paste milik temannya di TK lain atau diperoleh di internet. Sehingga, sering terjadi antara RPPH dengan apa yang dilakukan guru di kelsa; (3) Pembelajaran belum memperhatikan kecukupan jumlah dan keragaman jenis bahan ajar serta alat permainan edukatif dengan peserta didik; (4) Pendekatan saintifik meliputi kegiatan mengamati, menanya, mengumpulkan informasi, menalar, dan mengomunikasikan sangat jarang digunakan, karena dianggap tidak begitu cocok dengan tingkat perkembangan anak TK; (5) Kegiatan penutup jarang berisi: (a) kesimpulan sederhana dari kegiatan belajar, (b) nasihat-nasihat yang mendukung kebiasaan baik; dan (c) refleksi dan umpan balik terhadap kegiatan belajar; (d) kegiatan penenang seperti bernyanyi, bersyair, dan bercerita; (e) Menginformasikan rencana pembelajarn berikutnya. Kadang guru menutup pembelajaran dengan doa saja; dan (6) Belum dilakukan proses pembelajaran yang kontekstual yaitu pembelajaran yang terkait dengan tuntutan lingkungan alam dan sosial-budaya. Guru lebih berpatokan pada contoh-contoh yang ada pada panduan dan atau buku, jarang menghubungkan dengan kehidupan anak didik sehari-hari.

Tabulasi data hasil penelitian variabel product (X4) dari 105 orang responden ditunjukkan pada Tabel 05.

\section{Tabel 05}

Distribusi Frekuensi Skor Variabel Product

\begin{tabular}{|c|c|c|c|c|c|c|}
\hline \multirow{2}{*}{$\begin{array}{c}\text { No. } \\
1 \\
\end{array}$} & \multicolumn{3}{|c|}{ Interval Kelas } & \multirow{2}{*}{$\begin{array}{c}\text { Nilai } \\
\text { Tengah } \\
66\end{array}$} & \multirow{2}{*}{$\begin{array}{c}\text { Frekuensi } \\
\text { Absolut } \\
3\end{array}$} & \multirow{2}{*}{$\begin{array}{c}\text { Frekuensi } \\
\text { Relatif (\%) } \\
3\end{array}$} \\
\hline & 65 & - & 67 & & & \\
\hline 2 & 68 & - & 70 & 69 & 13 & 12 \\
\hline 3 & 71 & - & 73 & 72 & 27 & 26 \\
\hline 4 & 74 & - & 76 & 75 & 25 & 24 \\
\hline 5 & 77 & - & 79 & 78 & 24 & 23 \\
\hline 6 & 80 & - & 82 & 81 & 8 & 8 \\
\hline 7 & 83 & - & 85 & 84 & 5 & 5 \\
\hline Jumlah & & & & & 105 & 100 \\
\hline
\end{tabular}

Tabel 5 menunjukkan data variabel product (X4) 26\% pada nilai tengah 72 dan $24 \%$ pada nilai tengah 75. Berdasarkan hasil pengisian kuesioner dan wawancara masih ada kelemahan pada variabel product (X4) yaitu laporan hasil belajar belum diinformasikan secara lisan ke orang tua sesuai kebutuhan, khususnya untuk peserta didik yang mengalami keterlambatan belajar atau mengalami permasalahan perkembangan dan atau pertumbuhan.

Setelah transformasi data ke T skor kemudian dimasukkan ke dalam kuadran Glickman untuk mengetahui efektivitas pelaksanaan program Pendidikan Taman Kanak-Kanak (TK) di Kecamatan Seririt ditunjukkan pada Tabel 06.

Tabel 06

Kuadran Glickman

\begin{tabular}{cccc} 
& \multicolumn{2}{c}{ Skor T } & \\
$\begin{array}{c}\text { Variabel Contex } \\
(X 1)\end{array}$ & $\begin{array}{c}\text { Variabel } \\
\text { Input (X2) }\end{array}$ & $\begin{array}{c}\text { Variabel } \\
\text { Process (X3) }\end{array}$ & $\begin{array}{c}\text { Variabel } \\
\text { Product (X4) }\end{array}$
\end{tabular}

Keputusan (X1) Input (X2) Process (X3) Product (X4) 


\section{$\begin{array}{llllll}+ & - & + & + & + & \text { Efektif }\end{array}$}

Pada Tabel 6 dapat dilihat hasil evaluasi variabel contex (X1) berdasarkan skor T menunjukkan hasil positif $(+)$ semua dasar hukum terkait ijin pendirian TK, dokumen kelayakan, dokumen Rencana Induk Pengembangan (RIP) TK, dan dokumen rencana pencapaian standar penyelenggaraan TK dimiliki oleh TK di Kecamatan Seririt.

Hasil evaluasi variabel input (X2) berdasarkan skor T menunjukkan hasil (-) karena beberapa TK khususnya TK swasta belum memiliki fasilitas ruang kelas yang memadai untuk kegiatan pembelajaran, beberapa diantaranya menggunakan balai masyarakat sebagai tempat belajar. Masih minimnya sarana kesenian yang dimiliki TK di Kecamatan Seririt untuk melaksanakan kegiatan kesenian, khususnya pada TK swasta. Sebagian besar TK tidak memiliki ruang UKS (Usaha Kesehatan Sekolah) dengan kelengkapan administrasi dan P3K (Pertolongan Pertama Pada Kecelakaan) dan segala aktivitasnya. Hal ini akan berdampak pada kesiapan TK tersebut dalam menanggulangi apabila ada kecelakaan terhadap peserta didik saat bermain ataupun belajar. TK di Kecamatan Seririt belum memiliki tempat sampah yang tertutup dan tidak tercemar, beberapa ada tempat sampah tetapi tanpa tutup dan malah ada yang tidak memiliki tempat sampah. TK di Kecamatan Seririt sebagaian besar belum memiliki buku panduan pelaksanaan pendidikan. Dokumen laporan hasil pengawasan pelaksanaan kegiatan TK belum ada dimiliki oleh TK di Kecamatan Sririt. TK swasta di Kecamatan Seririt memiliki daya dukung yang jauh lebih minim dibandingkan TK Negeri, karena keterbatasan dana yang dimiliki yayasan untuk pengembangan sarana dan prasarana.

Hasil evaluasi variabel process (X2) berdasarkan skor T menunjukkan hasil positif $(+)$ karena dalam variabel process: (1) muatan pembelajaran sudah memperhatikan (a) Tahapan perkembangan anak, (b) Visi, misi dan tujuan Lembaga, (c) Kearifan local; dan (d) Keunggulan Lembaga; (2) Pelaksanaan pembelajaran dalam satu semester 17 minggu; (3) Pelaksanaan pembelajaran dalam satu minggu minimal 900 Menit; (4) Jika 5 hari belajar maka alokasi waktu belajar setiap harinya adalah 180 menit ( 3 jam), atau jika 6 hari kerja maka alokasi waktu belajar per harinya adalah 150 menit (2,5 jam) tidak termasuk jam istirahat; (4) Kalender pendidikan dan jadwal pelajaran telah dimiliki oleh masing-masing guru; (5) Kalender pendidikan sudah mencakup permulaan tahun ajaran, minggu efektif belajar, waktu pembelajaran efektif, hari libur, kegiatan-kegiatan perayaan hari besar nasional, kegiatankegiatan puncak tema, dan kegiatan-kegiatan Lembaga.

Selain itu, berdasarkan pengisian kuesioner dan wawancara dinyatakan: (1) Guru sudah melaksanakan pembelajaran sesuai dengan jumlah hari efektif dalam kalender pendidikan; (2) Guru sudah menyusun dan merencanakan program pembelajaran tahunan dan semester; (3) Pembalajaran dilakukan telah memenuhi prinsip belajar TK yaitu belajar melalui bermain, berorientasi pada perkembangan anak, berorientasi pada kebutuhan anak, berpusat pada anak, pembelajaran aktif, berorientasi pada nilai karakter, kecakapan hidup, dan demokratis; (4) Pembelajaran di dukung oleh lingkungan yang kondusif; (5) Pembelajaran telah memanfaatkan media belajar, sumber belajar, dan Narasumber Penggunaan media belajar, sumber belajar, dan narasumber yang ada di lingkungan TK bertujuan agar pembelajaran lebih kontekstual dan bermakna; (6) Lingkup pembelajaran sudah memenuhi semua program pengembangan yaitu nilai Agama dan Moral, Fisik-motorik, Kognitif, Bahasa, Sosial-emosional, dan Seni; (7) Pembelajaran telah mengembangkan kompetensi sikap, pengetahuan, dan keterampilan; dan (8) Pelaksanaan pembelajaran melalui bermain secara interaktif, inspiratif, menyenangkan, dan berpusat pada anak.

Begitu juga perencanaan kegiatan pembelajaran sudah memperhitungkan kecukupan waktu pelaksanaan pembelajaran. Kegiatan pembukaan pembelajaran mampu menyiapkan anak mengikuti proses pembelajaran, dimana pembukaan pembelajaran dilakukan dengan kegiatan Bermain (motorik kasar). Kegiatan inti pembelajaran mampu membentuk sikap, 
perolehan pengetahuan dan keterampilan. Pembelajaran mengutamakan interaksi antara anak, peserta didik dan pendidik, serta anak dan lingkungannya. Proses pembelajaran dilakukan salah satunya dengan mendorong perkembangan daya imajinasi anak. Proses pembelajaran dilakukan dengan menyenangkan yaitu dalam suasana bebas dan nyaman untuk mencapai tujuan pembelajaran. Selain itu, proses pembelajaran yang dilakukan sesuai dengan potensi, minat, karakter, tingkat perkembangan, dan kebutuhan anak.

Penilaian proses dan hasil belajar memenuhi sudah memenuhi prinsip: mendidik, berkesinambungan, objektif, akuntabel, transparan, sistematis, menyeluruh, dan bermakna. Penilaian telah mencakup semua aspek perkembangan yang dirumuskan dalam kompetensi sikap, pengetahuan, dan keterampilan. Teknik dan instrument penilaian yang sering digunakan antara lain: observasi, percakapan/wawancara, penugasan, unjuk kerja, penilaian hasil karya, pencatatan anekdot, dan atau portofolio. Pelaksanaan penilaian secara lebih teknis agar mengacu Pedoman Penilaian Perkembangan Anak yang disusun oleh Ditjen PAUD dan Dikmas, Kementerian Pendidikan dan Kebudayaan. Proses dan hasil penilaian telah dijadikan dasar memotivasi, mengembangkan, dan membina anak agar tumbuh dan berkembang secara optimal. Dimana penilaian telah dilakukan secara terencana, bertahap, dan terus menerus untuk mendapatkan gambaran tentang pertumbuhan dan perkembangan anak. Penilaian telah mencakup semua aspek pertumbuhan dan perkembangan anak baik sikap, pengetahuan maupun keterampilan. Hasil penilaian yang dibuat guru diharapkan mampu memberikan informasi yang bermanfaat bagi anak, orangtua, pendidik, dan pihak lain yang relevan.

Hasil evaluasi variabel product (X4) berdasarkan skor T menunjukkan hasil positif (+) karena laporan hasil belajar telah menunjukkan: (1) deskripsi pertumbuhan fisik; (2) perkembangan kompetensi sikap; (3) deskripsi pengetahuan; (4) deskripsi keterampilan anak. Laporan hasil belajar tertulis diberikan kepada orang tua setiap 6 bulan. Hasil belajar peserta didik telah menunjukkan: (1) penerapan kebiasaan yang baik dan menghindarkan kebiasaan buruk yang dapat mengganggu lingkungan; (2) tindakan berperilaku tertib dan patuh pada berbagai ketentuan dan peraturan; (3) Sikap menurut dan taat terhadap aturan-aturan berkenaan dengan masyarakat dan kepertingan umum; (4) Sifat halus dan baik dari sudut pandang tata bahasa maupun tata perilaku ke semua orang; (5) Sikap respek/hormat terhadap keberagaman, baik yang berbentuk fisik, sifat, adat, budaya, suku dan agama. Selain itu, peserta didik telah mengalami: (1) perkembangan pertumbuhan fisik normal yang dilatih dengan kegiatan-kegiatan sensomotorik, bermain, olah raga, dan gerak lagu; (2) perkembangan sikap yang baik, dibuktikan dengan kebiasaan-kebiasaan baik seperti menyapa, salim, ramah, menghormati orang lain, dan sikap baik lainya; (3) pengembangan pengetahuan tercapai sesuai dengan tujuan pembelajaran yang direncanakan; dan (4) pengembangan kompetensi keterampilan khususnya kecakapan hidup yang dapat diimplementasikan dalam keseharianya. Implementasi program pendidikan Taman Kanak-Kanak (TK) di Kecamatan Seririt juga telah menyebabkan guru mampu: (1) membantu peserta didik dalam menemukan nilai-nilai karakter; (2) menciptakan nilai-nilai sikap peduli siswa terhadap lingkungan sekolah; dan (3) membangkitkan sikap nasionalisme peserta didik terhadap perjuangan bangsa.

Hasil skor T pada Tabel 5 menunjukkan variabel contex (X1) positif $(+)$, variabel input (X2) negatif (-), variabel process (X3) positif, dan variabel product (X4) positif (+), sehingga hasil evaluasi CIPP pada Kuadran Glickman (+-++) menunjukkan pelaksanaan program pendidikan Taman Kanak-Kanak (TK) di Kecamatan Seririt termasuk kategori efektif.

Kendala yang menjadi penghambat pelaksanaan pelaksanaan program Pendidikan Taman Kanak-Kanak (TK) di Kecamatan Seririt adalah: (1) masih kurangnya fasilitas ruang kelas dan ruang UKS; (2) masih kurangnya sarana kesenian yang memadai untuk melaksanakan kegiatan kesenian; (3) Standar sanitasi lingkungan masih rendah, misalnya tempat sampah yang digunakan tanpa tutup, sehingga aroma sampah kadang mengganggu; (4) Kurangnya pelatihan terkait buku panduan pelaksanaan pendidikan dan penyusunan 
dokumen laporan hasil pengawasan pelaksanaan kegiatan TK untuk kepala sekolah; (5) Kurangnya pelatihan guru terkait penyusunan RPPM dan RPPH; (6) Masih rendahnya jumlah dan keragaman jenis bahan ajar serta alat permainan edukatif; (7) Kurangnya keterampilan guru dalam pendekatan pembelajaran saintifik dan pembelajaran yang kontekstual untuk pembelajaran TK. Jelas kendala-kendala tersebut menghambat pelaksanaan program pendidikan Taman Kanak-Kanak di Kecamatan Seririt, yang berdampak pada kurang maksimalnya kualitas program pendidikan TK di Kecamatan Seririt.

\section{Simpulan dan Saran}

Berdasarkan hasil penelitian dan pembahasan maka disimpulkan beberapa hal antara lain: (1) Pelaksanaan program Pendidikan Taman Kanak-Kanak (TK) di Kecamatan Seririt ditinjau dari contex berdasarkan skor T menunjukkan hasil positif $(+)$; (2) Pelaksanaan program Pendidikan Taman Kanak-Kanak (TK) di Kecamatan Seririt ditinjau dari input berdasarkan skor T menunjukkan hasil negatif (-); (3) Pelaksanaan program Pendidikan Taman Kanak-Kanak (TK) di Kecamatan Seririt ditinjau dari process berdasarkan skor T menunjukkan hasil positif (+); (4) Pelaksanaan program Pendidikan Taman Kanak-Kanak (TK) di Kecamatan Seririt ditinjau dari product berdasarkan skor T menunjukkan hasil positif (+); (5) Pelaksanaan program Pendidikan Taman Kanak-Kanak (TK) di Kecamatan Seririt ditinjau dari contex, input, process, dan product pada Kuadran Glickman menunjukkan pelaksanaan program pendidikan Taman Kanak-Kanak (TK) di Kecamatan Seririt termasuk kategori efektif; (6) Kendala-kendala yang dihadapi dalam pelaksanaan program Pendidikan Taman Kanak-Kanak (TK) di Kecamatan Seririt antara lain: (a) masih kurangnya fasilitas ruang kelas dan ruang UKS khususnya pada TK swasta; (b) masih kurangnya sarana kesenian yang memadai untuk melaksanakan kegiatan kesenian; (c) Standar sanitasi lingkungan masih rendah, misalnya tempat sampah yang digunakan tanpa tutup, sehingga aroma sampah kadang mengganggu; (d) Kurangnya pelatihan terkait buku panduan pelaksanaan pendidikan dan penyusunan dokumen laporan hasil pengawasan pelaksanaan kegiatan TK untuk kepala sekolah; (e) Kurangnya pelatihan guru terkait penyusunan RPPM dan RPPH; (f) Masih rendahnya jumlah dan keragaman jenis bahan ajar serta alat permainan edukatif; (g) Kurangnya keterampilan guru dalam pendekatan pembelajaran saintifik dan pembelajaran yang kontekstual untuk pembelajaran TK. Jelas kendala-kendala tersebut menghambat pelaksanaan program pendidikan Taman Kanak-Kanak di Kecamatan Seririt, yang berdampak pada kurang maksimalnya kualitas program pendidikan TK di Kecamatan Seririt.

Berdasarkan hasil penelitian dan pembahasan evaluasi CIPP disarankan: (1) perlunya disediakan sarana dan prasarana yang memadai baik di TK negeri maupun swasta; (2) perlu dilakukan pelatihan kepala sekolah untuk menyusun buku panduan pendidikan dan laporan hasil pengawasan kegiatan TK; dan (3) perlu dilakukan pelatihan untuk meningkatkan kompetensi pedagogic guru khususnya perencanaan pembelajaran dan penerapan model pembelajaran saintifik dan kontekstual..

\section{Daftar Pustaka}

Agung, A. A. G. dan Koyan, I W. 2016. Evaluasi Program Pendidikan. Singaraja: Universitas Ganesha.

Agung, A.A. Gede. 2016. Statistika Dasar untuk Pendidikan. Yogyakarta: Deepublish.

Agung, A.A. Gede. 2017. Evaluasi Pendidikan (Edisi-4). Singaraja: UNDIKSHA 
Agung, A.A. Gede. 2018. Metodologi Penelitian Kuantitatif (Perspektif Manajemen Pendidikan). Singaraja: UNDIKSHA

Anamara, A.G.V. 2014. Evaluasi Program Implementasi Standar PAUD. Jurnal Pendidikan Usia Dini, Vol. 8, Ed. 2: 301-311

Anwar dan Ahmad, Arsyad. 2007. Pendidikan Anak Usia Dini. Bandung: Alfabeta.

Arikunto, S. dan C.S.A. Jabar. 2009. Evaluasi Program Pendidikan Pedoman. Teoritis Praktis Bagi Mahasiswa dan Praktisi Pendidikan. Jakarta: Bumi Aksara.

Arikunto, Suharsimi. 2004. Evaluasi Program Pendidikan. Jakarta : Bumi. Aksara.

Christian Hosky Marak. 2016. Evaluasi Pelaksanaan Program Pendidikan dan Pelatihan Pasca Uji Kompetensi Guru Matematika di Pusat Pengembangan dan Pemberdayaan Pendidik dan Tenaga Kependidikan Matematika Yogyakarta.

Eliyarti, Cucu. 2005. Pemilihan dan Sumber Belajar Untuk Usia Dini. Dirjen DIKTI: Jakarta.

Frost, Joe, L., Wortham, Sue C., and Reifel, Stuart. 2007. Play and Child Development. Third Edition. Upper Saddle Rivers, New York: Pearson/Merill Prentice Hall.

Hartati, Sofia. 2005. Perkembangan Belajar Pada Anak Usia Dini. Jakarta: Departemen Pendidikan Nasional.

Indrawati, Maya dan Nugroho, Wido 2006. Mendidik dan Membesarkan Anak Usia PraSekolah. Jakarta: Prestasi Pustaka Publisher.

Irawan, Prasetya. 2006. Penelitian Kualitatif \& Kuantitatif Untuk IImu-IImu Sosial. Departemen IImu Adminstrasi FISIP UI.

Isjoni. 2005. Pendidikan Anak Usia Dini (Riau Pos) tersedia: Khatami.com-Majelis Kajian Tasawuf http://nurulkhatami.com, Generated 14 May, 2009.

Iskandar. 2012 Psikologi Pendidikan Sebuah Orientasi Baru. Jambi: PT. Gaung Persada.

Jalal, Fasli. 2002. Belajar dan Pembelajaran Dalam Taraf Usia Dini. Ikrar Mandiri Abadi: Jakarta.

Kasrani. 2016. Evaluasi Program Pendidikan Anak Usia Dini (PAUD). Jurnal Manajemen Pendidikan, Vol. 25, No. 2: 233-243

Kemendikbud. 2014a. Peraturan Menteri Pendidikan Dan Kebudayaan Republik Indonesia Nomor 137 Tahun 2014, tentang Standar PAUD.

Kemendikbud. 2014b. Peraturan Menteri Pendidikan Dan Kebudayaan Republik Indonesia Nomor 146 Tahun 2014, tentang Kurikulum 2013 Pendidikan Anak Usia Dini.

Kemendikbud. 2015. Petunjuk Teknis Penyelenggaraan Taman Kanak-Kanak. Jakarta: Kemendikbud Dirjen PAUD 
Kemendikbud. 2015b. Kurikulum Pendidikan Usia Dini (Apa, Mengapa, dan Bagaimana). Jakarta: Kemendikbud

Kountour, R. 2005. Metode Penelitian untuk Penulisan Skripsi dan Tesis. Jakarta: PPM

Marsitoh. 2014. Strategi Pembelajaran TK. Tanggerang Selatan: Universitas Terbuka

Miles, M.B, Huberman,A.M, dan Saldana,J. 2014. Qualitative Data Analysis, A. Methods Sourcebook Edition 3.

Moleong, Lexy J. 2008. Metodologi Penelitian Kualitatif. Bandung: PT Remaja Rosdakarya.

Mulyatiningsih, Endang. 2011. Metode Penelitian Terapan Bidang Pendidikan. Bandung: Alfabeta.

Nasution. 2003. Metode Research. Jakarta : PT. Bumi Aksara.

Peraturan Menteri Pendidikan dan Kebudayaan Republik Indonesia Nomor 137 Tahun 2014 Tentang Standar Nasional Pendidikan Anak Usia Dini.

Peraturan Menteri Pendidikan dan Kebudayaan Republik Indonesia Nomor 146 Tahun 2014 Tentang Kurikulum 2013 Pendidikan Anak Usia Dini

Rahman, S. Hibana,. 2005. Konsep Dasar Pendidikan Anak Usia Dini. Jogyakarta: PT. Grafindo Liter Media.

Sudijono, Anas . 2008. Pengantar Evaluasi Pendidikan. Jakarta: Raja. Grafindo Persada.

Sugiyono, 2008. Metode Penelitian Pendidikan Pendekatan Kuantitatif, Kualitatif, dan R\&D. Bandung: Alfabeta.

Sukmadinata. Nana Syaodih 2005. Metode Penelitian Pendidikan. Jakarta: Remaja Rosda Karya.

Tayibnapis, Farida Yusuf, 2008, Evaluasi Program dan Instrumen Evaluasi. Jakarta: PT. Rineka Cipta.

Undang-Undang Republik Indonesia Nomor 20 Tahun 2003 tentang Sistem Pendidikan Nasional.

Wirawan. 2012. Evaluasi: Teori, Model, Standar, Aplikasi, dan Profesi. Depok: PT Raja Grafindo Persada.

Wulan, Ratna Ana. 2013. Pengertian dan Esensi Konsep Evaluasi, Asesmen, Tes dan Pengukuran. Jakarta: Universitas Pendidikan Indonesia. 